\title{
PENGARUH STRATEGI PEMBELAJARAN DAN MOTIVASI BERPRESTASI TERHADAP KEMAMPUAN MEMBACA TEKS NARATIF BAHASA INGGRIS SISWA SMP NEGERI DI KABUPATEN LABURA
}

\author{
Rika Syahmewah Munthe ${ }^{1}$, Keysar Panjaitan ${ }^{2}$ \\ Pascasarjana Universitas Negeri Medan ${ }^{1,2}$ \\ rika_syahmewah@yahoo.com ${ }^{l}$
}

\begin{abstract}
Abstrak: Penelitian ini bertujuan untuk mengetahui: (1) hasil belajar Bahasa Inggris siswa yang diajar dengan strategi pembelajaran Quantum dibandingkan dengan siswa yang diajar dengan strategi pembelajaran ekspositori; (2) hasil belajar Bahasa Inggris siswa yang memiliki Motivasi berprestasi tinggi dengan hasil belajar siswa yang memiliki Motivasi berprestasi rendah; (3) ada tidaknya interaksi antara strategi pembelajaran dan Motivasi berprestasi siswa terhadap hasil belajar Bahasa Inggris. Metode penelitian yang digunakan adalah kuasi eksperimen dengan desain faktorial $2 \times 2$. Uji statistik yang digunakan adalah statistik deskriptif untuk menyajikan data dan dilanjutkan dengan statistik inferensial dengan menggunakan ANAVA dua jalur dengan taraf signifikan $\alpha=0,05$ yang dilanjutkan dengan uji Scheffe. Sebelumnya dilakukan uji analisis berupa uji nornalitas dan uji homogenitas. Hasil penelitian menunjukkan: (1) hasil belajar Bahasa Inggris siswa yang diajarkan dengan strategi pembelajaran Quantum lebih tinggi dari pada hasil belajar Bahasa Inggris siswa yang diajarkan dengan strategi pembelajaran ekspositori; (2) hasil belajar Bahasa Inggris siswa yang memiliki Motivasi berprestasi tinggi lebih tinggi dari pada hasil belajar Bahasa Inggris siswa yang memiliki Motivasi berprestasi rendah; (3) terdapat interaksi antara strategi pembelajaran dengan Motivasi berprestasi dalam mempengaruhi hasil belajar siswa.
\end{abstract}

Kata Kunci: strategi pembelajaran, motivasi berprestasi, membaca teks naratif bahasa inggris

Abstract: This study aims to determine: (1) the results of English learning students who are taught by Quantum learning strategies than students taught by expository strategy; (2) the results of English learning students who have high achievement motivation with learning outcomes of students who have low achievement motivation; (3) whether there is interaction between the learning strategies and achievement motivation of students to learn English results. The method used is a quasi-experimental design with $2 \times 2$ factorial statistical test used is descriptive statistics to present data and continued with inferential statistics by using ANOVA two paths with significance level $\alpha=0.05$, followed by Scheffe test. Previous test analysis form nornalitas test and homogeneity test. The results showed: (1) the results of English learning students taught with instructional strategies Quantum higher than the results of English learning students taught by expository strategy; (2) the results of English learning students who have high achievement motivation is higher than the results of English learning students who have low achievement motivation; (3) there is interaction between learning strategy and achievement motivation in influencing student learning outcomes.

Keywords: learning strategies, achievement motivation, reading the narrative text english

\section{PENDAHULUAN}

Pelajaran Bahasa Inggris di SMP/MTs bertujuan peserta didik memiliki kemampuan yaitu; mengembangkan kompetensi dalam bentuk tulisan dan lisan dalam tingkatan fungsional, memiliki kesadaran dan hakikat tentang pentingnya Bahasa Inggris untuk meningkatkan daya saing dalam dunia global dan mengembangkan pemahaman peserta didik tentang keterkaitan antara bahasa dan budaya.
Ruang Lingkup mata pelajaran Bahasa Inggris di SMP/MTs meliputi: (1) kemampuan berwacana,yakni kemampuan memahami dan/atau menghasilkan teks lisan dan/atau tulis yang direalisasikan dalam empat keterampilan berbahasa, yakni mendengarkan, berbicara, membaca dan menulis secara terpadu untuk mencapai tingkat literasi functional, (2) kemampuan memahami dan menciptakan berbagai teks fungsional pendek dan monolog 
serta esai berbentuk procedure, descriptive dan recount. Gradasi bahan ajar tampak dalam penggunaan kosa kata, tata bahasa dan langkahlangkah retorika, (3) kompetensi pendukung, yakni kompetensi linguistik (menggunakan tata bahasa dan kosa kata, tata bunyi dan tata tulis), kompetensi sosiokultural (menggunakan ungkapan dan tindak bahasa secara berterima dalam berbagai konteks komunikasi), kompetensi strategi (mengatasi masalah yang timbul dalam proses komunikasi dengan berbagai cara agar komunikasi dapat tetap berlangsung) dan kompetensi pembentuk wacana (menggunakan piranti pembentuk wacana).

Membaca pada hakikatnya melibatkan tiga komponen dasar dari membaca, yaitu recording, decoding dan meaning. Recording merujuk pada kata dan kalimat kemudian mengasosiasikan dengan bunyi-bunyinya sesuai dengan sistem tulisan yang digunakan sedangkan proses decoding (penyandian) merujuk pada proses penterjemahan rangkaian grafis ke kata-kata. Sementara proses meaning (memahami makna) berlangsung melalui dua proses yaitu proses perseptual dan kognitif (Rahim, 2005:3).

DePorter (2007) menguraikan bahwa pembelajaran quantum merupakan cara-cara baru yang memudahkan proses belajar lewat pemaduan unsur seni dan pencapaianpencapaian yang terarah. Proses belajar mengajar adalah fenomena yang kompleks, segala sesuatunya berarti, setiap kata, pikiran, tindakan dan asosiasi dan sejauh mana guru mengubah lingkungan, presentasi dan rancangan pengajaran, sejauh itu pula proses belajar berlangsung. Pembelajaran quantum adalah pembelajaran yang mengorkestrasikan berbagai interaksi yang berada didalam dan di sekitar momen belajar, sehingga kemampuan dan bakat alamiah siswa berubah menjadi kemampuan aktual. Pembelajaran quantum berfokus pada hubungan dinamis dalam lingkungan kelas serta interaksi yang mendirikan landasan dan kerangka untuk belajar. Strategi pembelajaran quantum memiliki kerangka rancangan belajar yaitu "Tandur" (Tumbuhkan, Alami, Namai, Demonstrasikan, Ulangi dan Rayakan ).

Revisi dan penamaan kembali taksonomi Bloom, menjadi taksonomi belajar disitasi oleh Anderson et al (2001) disitasi oleh Arends (2004:116) dilakukan untuk kerangka kerja pengklasifikasian tujuan pembelajaran dan cara menilainya, (1) ingatan, mencakup kemampuan mengingat tentang hal yang telah dipelajari dan tersimpan dalam ingatan, (2) pemahaman, mencakup kemampuan menangkap arti dan makna dari pesan, pembicaraan, tulisan dan grafik, (3) penerapan mencakup kemampuan menerapkan dan menggunakan prosedur untuk mengatasi situasi yang baru, (4) analisis, mencakup kemampuan merinci suatu kesatuan dalam bagian-bagian sehingga struktur keseluruhan dapat dipahami dengan baik, (5) evaluasi, mencakup kemampuan membentuk pendapat tentang beberapa hal berdasarkan kriterian dan standar tertentu, (6) kreativitas, mencakup kemampuan menggabungkan beberapa bagian menjadi suatu bentuk yang koheren atau berfungsi secara menyeluruh, mengorganisasi bagian-bagian menjadi struktur yang baru.

Reigeluth (1983) menyatakan bahwa hasil belajar secara umum dapat dikategorikan menjadi tiga indikator, yakni: (1) efektivitas pembelajaran yang biasanya diukur dari tingkat keberhasilan (prestasi) peserta didik dari berbagai sudut, (2) efisien pembelajaran, yang bisanya diukur dari waktu belajar dan atau biaya pembelajaran, (3) daya tarik pembelajaran yang selalu diukur dari tendensi peserta didik ingin belajar secara terus menerus. Secara spesifik, hasil belajar yaitu suatu kinerja (performance) yang diindikasikan suatu kapabilitas (kemampuan yang diperoleh).

Merril (1983) seperti yang disitasi Reigeluth dan Moore (1983:53) mengemukakan adanya tiga jenis hasil belajar dalam empat kategori yaitu; mengingat kata perkata secara harfiah (remember verbatim), mengingat dengan mengubah informasi yang diperolehnya dengan mempergunakan kalimat sendiri (remember paraphased), si belajar menggunakan pengaturan secara umum untuk memperoleh informasi khusus (use a generality), menenemukan sesuatu yang baru secara umum (find a generality).

$$
\text { Menurut Reigeluth }
$$
instructional outcomes are the various effects that provide a measure of value of alternative methods under different conditions. Hasil belajar yang dicapai seseorang dapat diketahui bila diadakan pengukuran dari pengetahuan seseorang itu. Untuk mengukur sampai dimana tingkat pengetahuan seseorang itu harus ada suatu alat pengukur tertentu yang fungsinya adalah mengukur pengetahuan hasil belajar. Alat atau prosedur yang dipergunakan 
dinamakan test. Test itu berupa pertanyaan atau soal - soal yang harus dijawab.

Membaca adalah aktivitas berpikir dan memiliki tingkat prbedaan pemahaman. Pemahaman adalah label untuk berbagai keterampilan yang melibatkan pemerolehan makna dari suatu teks bacaan. Burns (1993) membagi pemahaman menjadi empat tingkat, yaitu: literal comprehension, interpretative comprehension, critical comprehension, and creative comprehension. Pemahaman literal mengacu pada pemerolehan informasi secara langsung dari halaman cetak. Dasar dari pemahaman literal adalah mengenali ide utama ,menyatakan sebab akibat efek-rinci, dan urutan. Dengan mudah pembaca menggarisbawahi informasi yang diinginkan.

Ruang Lingkup mata pelajaran Bahasa Inggris di SMP/MTs meliputi: (1) kemampuan berwacana,yakni kemampuan memahami dan/atau menghasilkan teks lisan dan/atau tulis yang direalisasikan dalam empat keterampilan berbahasa, yakni mendengarkan, berbicara, membaca dan menulis secara terpadu untuk mencapai tingkat literasi functional, (2) kemampuan memahami dan menciptakan berbagai teks fungsional pendek dan monolog serta esai berbentuk descriptive, recount dan narrative. Gradasi bahan ajar tampak dalam penggunaan kosa kata, tata bahasa dan langkahlangkah retorika, (3) kompetensi pendukung, yakni kompetensi linguistik (menggunakan tata bahasa dan kosa kata, tata bunyi dan tata tulis), kompetensi sosiokultural (menggunakan ungkapan dan tindak bahasa secara berterima dalam berbagai konteks komunikasi), kompetensi strategi (mengatasi masalah yang timbul dalam proses komunikasi dengan berbagai cara agar komunikasi dapat tetap berlangsung) dan kompetensi pembentuk wacana (menggunakan piranti pembentuk wacana).

Hornby (1989) menyatakan bahwa teks narasi adalah komposisi yang terdiri dari cerita. Ini berarti narasi yang berkaitan dengan urutan yang kejadian selama periode tertentu. Teks naratif memiliki setidaknya tiga unsur yang membuatnya lebih hidup yaitu: (1) plot ( alur) yaitu urutan peristiwa yang terjadi dalam narasi. (2) setting yaitu waktu dan tempat di mana acara terjadi dan tidak hanya lokasi fisik seperti kota, hutan, sungai, gunung,cuaca dan lain lain dan (3) point of view yaitu sudut pandang yang membahas secara langsung menggunakan kata ganti orang pertama sementara sudut pandang yang berdiri kembali dari peristiwa menggunakan kata ganti orang ketiga dan mengacu pada karakter.

Goodman (1978:18) states that reading viewed as an interaction process involves three factors, namely conceptual ability, background of knowledge and process strategies. Reading is just not a decoding system of symbol but an interaction between reader and writer's knowledge background in the text. ( membaca dipandang sebagai sebuah proses interaksi yang melibatkan tiga faktor, yaitu kemampuan konseptual, latar belakang pengetahuan dan strategi proses. Membaca bukan hanya decoding sistem simbol, tetapi interaksi antara latar belakang pengetahuan pembaca dan penulis dalam teks).

Pendapat senada dipaparkan oleh Hernowo (2004:72) dalam bukunya Quantum Reading, membaca dapat mengintegrasikan diri kita, karena dengan membaca seseorang harus mencerna apa maksud sebuah kata, kalimat dan alinea. Seseorang harus berpikir mengolah apa saja yang diterima dari kalimat yang dibacanya lebih jauh dijelaskannya membaca tanpa memahami atau yang disebut Hernowo (2004:48) mengikat makna adalah perbedaan membaca pemahaman dan membaca hanya huruf-huruf yang ada di buku atau teks tanpa dapat membaca pikiran si pengarangnya.

Herbert menyatakan (1989:11) Reading comprehension is an understanding process in reading the text which includes decoding symbols and analyzing idea gained from the symbols, pemahaman membaca adalah proses pemahaman dalam membaca teks yang mencakup simbol decoding dan menganalisis ide yang diperoleh dari simbol-simbol. Hal senada juga dinyatakan Devine (1986) bahwa pemahaman membaca adalah proses menggunakan sintaksis, semantik dan informasi retorika yang ditemukan dalam teks dicetak akan direkonstruksi dalam pikiran pembaca. Hasil dari pemahaman adalah interaksi antara pembaca dan teks. Berdasarkan pernyataan tersebut, memahami teks berarti memahami apa yang telah dibaca. Ini memiliki dua hal penting yaitu memperhatikan teks dengan melihat teksserta memahami pesan teks dengan berfokus pada hal-hal

Strategi berhubungan dengan cara menyampaikan pesan dalam pembelajaran. Strategi meliputi sifat, ruang lingkup, dan rangkaian kejadian yang mengandung pengalaman belajar. Strategi harus 
memperhitungkan tujuan yang telah ditetapkan dan mempertimbangkan karakteristik siswa. Strategi pembelajaran adalah rencana untuk mencapai tujuan pembelajaran yang dikembangkan dari metode-metode dan teknikteknik yang akan membantu siswa mencapai tujuan pembelajarannya. (Gerlach \& Ely, 1980: 174).

Richey and Seels (1994) menjelaskan bahwa strategi pembelajaran adalah spesifikasi untuk memilih dan mengurutkan kejadian dan aktivitas pembelajaran, yang meliputi penyajian materi, pemberian contoh, pemberian latihan serta pemberian umpan balik. Agar tujuan pembelajaran tercapai secara optimal maka semua aktivitas harus diatur dengan mempertimbangkan karakteristik peserta didik, media dan situasi di sekitar proses pembelajaran.

Dick, Carey and Carey (2005) menjelaskan bahwa strategi pembelajaran memuat lima komponen utama, yaitu : (1) aktivitas pembelajaran pendahuluan, (2) penyampaian informasi, (3) partisipasi siswa, (4) tes dan (5) kegiatan lanjutan. Suparman (1987) mendefenisikan strategi pembelajaran sebagai perpaduan dari : (1) urutan kegiatan instruksional, (2) metode instruksional, (3) media instruksional dan (4) waktu yang digunakan dalam proses pembelajaran, dari kedua defenisi di atas pada prinsipnya lebih menekankan pada aspek komponen dan prosedur pembelajaran. Menurut Dick and Carey strategi pembelajaran bukan hanya terbatas pada prosedur dan tahapan kegiatan belajar saja, melainkan termasuk juga pengaturan materi atau paket program pembelajaran yang akan disampaikan pada peserta didik.

\section{Sedangkan Romizowski}

berpendapat bahwa strategi pembelajaran merupakan suatu pendekatan menyeluruh yang dapat dibedakan menjadi dua strategi dasar, yaitu ekspositori (penjelasan) dan discovery (penemuan). Kedua strategi ini dapat dipandang sebagai dua ujung yang sejalan dalam suatu kontinum strategi. Disebutkan ekspositori karena strategi ini dimulai dengan penyajian informasi mengenai prinsip atau kaidah kemudian diikuti dengan tes penguasaan, penerapan dalam bentuk contoh dan penerapan pada situasi tertentu, hal ini erat kaitannya dengan pendekatan deduktif. Sedangkan strategi inquiri/discovery didasarkan pada teori belajar penemuan. Rangkaian belajar ini dimulai dari tindakan, pengertian, generalisasi dan kemudian dilanjutkan lagi dengan tindakan. Strategi ini erat hubungannya dengan pendekatan induktif.

Menurut Miarso (2005:530) "strategi pembelajaran adalah pendekatan menyeluruh pembelajaran dalam suatu sistem pembelajaran, yang berupa pedoman umum dan kerangka kegiatan untuk mencapai tujuan umum pembelajaran". Selanjutnya Suparman (2001) mendefenisikan strategi pembelajaran sebagai perpaduan dari (1) urutan kegiatan instruksional, (2) cara pengorganisasian materi pengajaran dan peserta didik, (3) peralatan dan bahan, dan (4) waktu yang digunakan dalam proses pembelajaran. Ketiga defenisi yang dikemukakan para ahli tersebut pada prinsipnya lebih menekankan pada aspek komponen dan prosedur pengajaran.

Terdapat prinsip-prinsip umum penggunaan strategi pembelajaran (Sanjaya, 2008: 131), yaitu: (1) berorientasi pada tujuan, yaitu dalam pembelajaran tujuan merupakan komponen yang utama, keberhasilan suatu strategi tergantung pada tercapainya tujuan, (2) aktivitas, strategi pembelajaran harus dapat mendorong aktivitas siswa (3) individualitas, strategi pembelajaran pada hakikatnya ingin mencapai perubahan prilaku setiap siswa dan (4) integritas, strategi pembelajaran harus dapat mengembangkan seluruh aspek kepribadian siswa secara terintegrasi.

Menurut Davies (1981) terdapat lima aspek strategi pembelajaran antara lain: (1) peran efisiensi dan efektivitas, (2) pemilihan metode-metode pembelajaran, (3) struktur pelajaran, (4) persiapan pelajaran, (5) pengaturan-pengaturan pembelajaran. Kelima aspek ini dipandang sebagai komponenkomponen yang diperlukan dalam strategi pembelajaran. Pada setiap tahap dibuat keputusan-keputusan dan perlu dikompromikan. Strategi pembelajaran tidak berasal dari kawasan yang sempit tetapi merupakan produk dari pikiran yang inovatif, hasil dari pengalaman-pengalaman sebelumnya. Melibatkan suatu proses kreatif, membutuhkan perpaduan baik seni maupun ilmu pembelajaran.

Merill (1994) mengklasifikasikan strategi pembelajaran atas tiga dasar, (1) strategi penyajian, (2) strategi pengorganisasian dan (3) strategi pengelolaan. Sedangkan Suparman (2001) mengatakan bahwa strategi pembelajaran terkandung empat pengertian 
sebagai berikut : (1) urutan kegiatan pembelajaran, yaitu urutan kegiatan pengajar dalam menyampaikan isi pelajaran kepada siswa, (2) Metode pengajaran, yaitu cara pengajar efesien, (3) Media pembelajaran, yaitu peralatan dan bahan pengajaran yang digunakan pengajar dan siswa dalam kegiatan instruksional, dan (4) Waktu yang digunakan oleh pengajar dan siswa dalam menyelesaikan setiap langkah dalam kegiatan pembelajaran.

Secara implisit Reigeluth (1983:97) menjelaskan bahwa kondisi pembelajaran merupakan faktor yang signifikan memberikan pengaruh dalam menentukan metode pembelajaran yang digunakan guru. Kondisi pembelajaran mencakup:(1) karakteristik tujuan yang hendak dicapai, (2) karakteristik hambatan untuk mencapai tujuan dan (3) karakteritik siswa. Karakteristik siswa meliputi kecepatan belajar., kecerdasan intelektual, social ekonomi, dan lain-lain.

Reigeluth (1983) membagi strategi pembelajaran menjadi tiga bagian yaitu (1) strategi pengorganisasian pembelajaran yang merupakan metode untuk mengorganisasikan isi dari mata pelajaran yang akan diajarkan, (2) Strategi penyampaian pembelajaran yaitu berupa metode untuk menyampaikan mata pelajaran, dan (3) strategi pengelolaan pembelajaran yaitu berupa metode untuk mengambil keputusan berkaitan dengan komponen-komponen strategi pengorganisasian dan

Salah satu cara yang dapat dilakukan oleh guru antara lain, melakukan senam otak. Senam otak adalah serangkaian gerakan tubuh yang sederhana digunakan untuk semua bagian otak guna meningkatkan kemempuan belajar. Senam otak sangat baik dilakukan pada awal proses pembelajaran (Gunawan, 2006:270). Gerakan-gerakan sederhana latihan senam otak dapat menyeimbangkan kembali fungsi-fungsi otak (Prashing, 2007:179)

Gerakan senam otak yang sederhana antara lain : (1) gerakan silang, yaitu menggerakkan tangan kanan bersamaan dengan kaki kiri dan tangan kiri bersamaan dengan kaki kanan, bergerak ke depan, ke samping, ke belakang atau jalan di tempat, tangan menyentuh lutut yang berlawanan, (2) 8 tidur, yaitu membuat angka 8 tidur tiga kali tiap tangan, kemudian tiga kali dengan kedua tangan atau juga dapat dilakukan dengan menggunakan siku, (3) coretan ganda, yaitu menggambar dengan kedua tangan pada saat yang sama, ke dalam, ke luar, ke atas, ke bawah, (4) putaran leher, yaitu tundukan kepala ke depan dan pelan-pelan memutar leher dari satu sisi ke sisi lainnya lalu ulangi dengan bahu diturunkan, serta (5) mengisi energi, yaitu duduk di kursi dengan santai dan meletakkan dahi diantara kedua tangan di atas meja, tarik nafas sambil menegakkan kepala, tengkuk dan punggung bagian atas. (Dennison. 2002). DePorter (2007) menyatakan strategi pembelajaran quantum memiliki lima prinsip atau kebenaran tetap yang mempengaruhi aspek pembelajaran yaitu segalanya berbicara, segalanya bertujuan, pengalaman sebelum pemberian arti, akui setiap usaha dan jika layak dipelajari maka layak pula dirayakan.

Menurut Ausbel dalam Driscoll (1993) bahwa pada dasarnya pembelajaran ekpositori (expository learning) sama dengan pembelajaran yang terjadi dengan belajar menerima. Hal senada dikemukakan Romiszowski (1981) bahwa pendekatan ekspositori adalah pendekatan pembelajaran yang didasarkan pada proses belajar bermakna menerima (meaningfull reception learning). Strategi pembelajaran ekspositori merupakan bentuk dari pendekatan pembelajaran yang berorientasi kepada guru. Peranan guru dalam proses pembelajaran sangat dominan. Guru menyampaikan materi secara terstruktur dengan harapan materi pelajaran yang disampaikan dapat dikuasai siswa dengan baik. Lebih lanjut Davies (1991:233) mengatakan "biasanya pelajar tidak mempunyai banyak kesempatan untuk memberi tanggapan". Peserta didik lebih dominan pasif dan tidak berpartisipasi aktif dalam kegiatan pembelajaran.

Davies (1991:214) menyatakan motivasi ialah kekuatan yang tersembunyi di dalam diri kita, yang mendorong kita untuk berkelakuan dan bertindak dengan cara yang khas. Kadang kekuatan itu berpangkal pada naluri, kadang pula berpangkal pada suatu keputusan rasional, tetapi lebih sering lagi hal itu merupakan perpaduan kedua proses tersebut. Luthans (1995) juga mengemukakan bahwa motivasi merupakan seperangkat proses dorongan , arahan, dan pemeliharaan perilaku ke arah suatu sasaran. Winkel (2009:150) mengatakan motivasi belajar adalah keseluruhan daya penggerak fisik di dalam diri siswa yang menimbulkan kegiatan belajar, menjamin kelangsungan kegiatan belajar, dan memberikan arah pada kegiatan pembelajaran itu demi mencapai suatu tujuan. 
McCelland (1949) menyatakan bahwa pemahaman tentang motivasi akan semakin mendalam apabila disadari bahwa setiap orang mempunyai tiga jenis kebutuhan yaitu need for achievement (motivasi berprestasi), need for power (kekuasaan), need for affiliation (motivasi afiliasi). Motivasi merupakan struktur dari berbagai motivasi yang timbul. Iskandar (2009) menyatakan bahwa motivasi adalah segala daya yang mendorong seseorang untuk melakukan sesuatu perbuatan. Disini dijelaskan bahwa motivasi tersebut sangat besar sekali pengaruhnya terhadap tindakan atau perbuatan seseorang karena sesuatu atau dorongan yang ditimbulkan motivasi tersebut sudah terikat pada suatu tujuan. Keller dalam Reigeluth ( 1983:390) menjelaskan bahwa motivasi dan belajar merupakan dua hal yang saling mempengaruhi. Belajar adalah perubahan tingkah laku secara relatif permanen dan secara potensial terjadi sebagai hasil dari praktik atau penguatan yang dilandasi tujuan untuk mencapai tujuan tertentu.

Nasution (2003) motivasi adalah suatu proses untuk menggiatkan motivasi atau motivasi-motivasi lain menjadikan tindakan atau perilaku untuk memuaskan atau memenuhi kebutuhan atau untuk mencapai tujuan.Beberapa cara untuk menumbuhkan motivasi adalah melalui cara mengajar yang bervariasi, mengadakan pengulangan informasi, memberikan stimulus baru misalnya melalui pertanyaan kepada peserta didik untuk menyalurkan keinginan belajarnya, menggunkan media dan alat bantu yang menarik perhatian peserta didik seperti gambar, foto, diagram dan sebagainya.

Caplin (1999) mendefenisikan motivasi berprestasi adalah kecenderungan memperjuangkan kesuksesan atau memperoleh hasil yang didambakan. Motif berprestasi menunjukkan kecenderungan yang lebih besar pada proses dibandingkan dengan hasil. Prinsipnya berbuat yang lebih baik dan lebih cepat terlebih dahulu kemudian barulah hasilnya didapatkan. Individu yang mempunyai motif berprestasi tinggi akan bekerja dan berusaha dengan kemampuan sendiri dan tidak bergantung kepada orang lain serta merasa bangga dengan hasil usaha sendiri. Tentu saja berbeda halnya bagi individu yang mempunyai motif berprestasi rendah akan cenderung memilih cara-cara singkat dan tidak penuh resiko untuk menyelesaikan beberapa pekerjaanya tanpa peduli bagaimana cara mengerjakan yang lebih baik atau siapa yang mengerjakannya.

Munandar (1992:67) juga menjelaskan bahwa motivasi berprestasi adalah berpikir kreatif, berpikir untuk memberikan berbagai kemungkinan jawaban berdasarkan informasi yang diberikan dengan penekanan pada keragaman jumlah, kesesuaian, lebih bebas dan terbuka. Kajian Munandar selaras dengan Seifert (1992:89), bahwa motivasi berprestasi memiliki empat ciri utama yaitu : (1) kelancaran (fluency), (2) kelenturan (flexibility), (3) keaslian (originality), dan (4) perluasan (elaboration). Menurut Noe, karakteristik orang yang memiliki motivasi berprestasi, yaitu : (1) sangat baik untuk memunculkan gagasangagasan, (2) melihat obyek permasalahan dari berbagai perspektif yang memberi makna dan nilai, dan (3) tertarik pada obyek orang, budaya dan seni. The divergent style is the second style that engages the student in a discovery process that of directing the path of discovery 'o that of leading the learner to discovering alternatives. Dalam implementasi pembelajaran Bahasa Inggris , guru harus mampu memberikan pertanyaan , masalah dan pengaturan situasi belajar yang mendorong siswa untuk memberikan ragam respon.

Motivasi berprestasi berperan penting dalam mengembalikan motivasi yang semula biasa menjadi suatu tujuan tertentu. Sedangkan motivasi itu berdiri sendiri mempunyai arti yaitu proses aktualisasi energi psikologis yang dapat menggerakkan seseorang untuk beraktivitas, sekaligus menjamin keberlangsungan aktifitas tersebut, dan juga menentukan arah aktivitas terhadap pencapaian tujuan. Indikator - indikator ini merujuk pada pendapat yang dikemukakan oleh Mc.Clelland, dkk. (1976:89) dan Abdullah (Azwar, 1999) dalam Hidayat $(2008 ; 80)$ dalam penelitiannya tentang hubungan motivasi berprestasi , menyebutkan ada 9 indikator motivasi berprestasi, yaitu sebagai berikut: (1). Memiliki semangat yang tinggi untuk mencapai kesuksesan, (2). memiliki tanggungjawab, (3). Memiliki rasa percaya diri, (4). Memilih untuk melakukan tugas yang menantang, (5). Menunjukkan usaha keras dan tekun dalam mencapai tujuan yang bersifat lebih baik, (6). Memupuk keberanian untuk mengambil resiko, (7). Adanya keinginan untuk selalu unggul dari orang lain, (8). Kreatif dan selalu menentukan tujuan yang realistik, dan (9). Motivasi sendiri muncul karena ada motif atau penggerak. 
Dari urain di atas dapat dikatakan bahwa pembelajaran kemampuan berbahasa merupakan sebuah proses yang cukup rumit karena banyak hal yang menentukan berhasil atau tidaknya suatu pembelajaran bahasa tersebut. Hal yang berkaitan dengan keberhasilan pembelajaran emampat kemampuan berbahasa, menurut pendapat pakar pembelajaran yang mengemukakan definisi motivasi berprestasi, diantaranya; (1). Coffer (1964:76) menyatakan bahwa motivasi ialah dorongan, hasrat, kemauan, alasan, atau tujuan yang menggerakkan orang untuk melakukan sesuatu, (2). Brown (200:78) yang menyatakan bahwa motivasi ialah dorongan dari dalam, dorongan sesaat, emosi, atau keingianan yang menggerakkan seseorang untuk melakukan sesuatu, (3). Lambert (1972: 67) yang menyatakan bahwa motivasi ialah alasan untuk mencapai tujuan secara keseluruhan. Berdasarkan sintesis terhadap beberapa teori, konsep dan pendapat di atas, dapat disimpulkan bahwa karakteristik motivasi berprestasi siswa SMP dalam menerima pembelajaran Bahasa Inggris mencakup , yaitu: (1) orientasi perhatian, (2) pemecahan masalah, dan (3) aktualisasi ide.

Berdasarkan uraian di atas maka dapat disimpulkan bahwa motif berprestasi merupakan suatu daya dalam mental seseorang untuk melakukan suatu kegiatan yang lebih baik, lebih cepat, lebih efektif dan lebih efisien daripada kegiatan yang dilaksanakan sebelumnya.

Masalah penelitian ini dapat dirumuskan sebagai berikut: (1) Apakah hasil belajar Kemampuan Membaca Bahasa Inggris Siswa dalam memahami teks Naratif pada tahap pemahaman Literal Comprehension dan Interpretative Comprehension yang diajar dengan strategi pembelajaran Quantum daripada peserta didik yang diajar dengan strategi pembelajaran Ekspositori? (2) Apakah terdapat perbedaan hasil belajar Kemampuan Membaca Bahasa Inggris Siswa dalam memahami teks Naratif pada tahap pemahaman Literal Comprehension dan Interpretative Comprehension peserta didik yang memiliki Motivasi belajar tinggi dan Motivasi Belajar Rendah? (3) Apakah terdapat interaksi antara strategi pembelajaran dengan Motivasi belajar dalam mempengaruhi hasil belajar Kemampuan Membaca Bahasa Inggris Siswa dalam memahami teks Naratif pada tahap pemahaman Literal Comprehension dan Interpretative Comprehension?

\section{METODE}

Penelitian ini dilaksanakan di SMP Negeri 1 Aek Kota Batu dan SMP Negeri 2 Sumberejo Kabupaten Labuhan Batu Utara. Populasi penelitian ini adalah seluruh siswa berjumlah 144 siswa, yang terdiri dari 4 kelas dengan rata-rata setiap kelas jumlah 35 siswa setiap kelasnya dan SMP Negeri 2 Sumberjo Kabupaten Labuhan Batu Utara berjumlah 140 siswa, yang terdiri dari 4 kelas dengan jumlah 35 siswa setiap kelasnya.

Setiap kelas memiliki karakteristik yang sama, artinya setiap kelas tidak memiliki siswa yang pernah tinggal kelas, siswa rata-rata memiliki umur yang tidak jauh berbeda dan menggunakan kurikulum yang sama. Pembagian kelas tidak dilakukan berdasarkan rangking, sehingga tidak terdapat kelas unggulan yang karakteristik siswanya berbeda.

Dari keseluruhan populasi ditetapkan 2 (dua) kelas yang menjadi sampel. Masingmasing kelas memiliki karakteristik yang sama seperti penggunaan kurikulum, setiap kelas tidak memiliki siswa yang pernah tinggal kelas dan rata-rata memiliki umur yang tidak jauh berbeda. Sampel penelitian diperoleh dengan menggunakan cara cluster random sampling atau teknik pengambilan sampel secara acak.

Ditentukan satu kelas VII SMP Negeri 1 Aek Kota Batu sebagai kelas eksperimen I yang diajarkan dengan Strategi Pembelajaran Quantum dengan jumlah siswa 35 orang, sedangkan satu kelas VII SMP Negeri 2 Sumberjo sebagai kelas eksperimen II yang dibelajarkan dengan Strategi Pembelajaran Ekspositori dengan jumlah siswa 35 orang.

Metode yang dipergunakan dalam penelitian ini adalah metode quasi-eksperimen. Metode ini dipilih karena kelas yang dipakai untuk kelas pembelajaran yang sudah terbentuk sebelumnya dan variabel yang dikontrol adalah Strategi pembelajaran yang diaplikasikan. Desain penelitian yang digunakan dalam penelitian adalah ANAVA faktorial $2 \times 2$ sebagaimana terlihat pada tabel berikut : 
Tabel 1. Matrik Rancangan Penelitian

\begin{tabular}{|c|c|c|}
\hline $\begin{array}{c}\text { Strategi Pembelajaran } \\
\text { (A) } \\
\text { Metivasi }\end{array}$ & $\begin{array}{c}\text { Quantum } \\
\text { (A1) }\end{array}$ & $\begin{array}{c}\text { Ekspositori } \\
\text { (A2) }\end{array}$ \\
\hline $\begin{array}{c}\text { Tinggi } \\
\text { (B1) }\end{array}$ & A1B1 & A2B1 \\
\hline $\begin{array}{c}\text { Rendah } \\
\text { (B2) }\end{array}$ & A1B2 & A2B2 \\
\hline
\end{tabular}

Keterangan :

$\mathrm{A}=$ Strategi pembelajaran

B $=$ Motivasi Berprestasi

A1 = Strategi pembelajaran Quantum

A2 = Strategi pembelajaran Ekspositori

B1 = Motivasi berprestasi tinggi

B2 = Motivasi Berprestasi rendah

$\mathrm{A} 1 \mathrm{~B} 1$ = Hasil belajar siswa yang dibelajarkan dengan strategi pembelajaran Quantum yang memiliki Motivasi berprestasi tinggi

A1B2 = Hasil belajar siswa dibelajarkan dengan strategi pembelajaran Quantum yang memiliki Motivasi Berprestasi rendah

A2B1= Hasil belajar siswa yang dibelajarkan dengan strategi pembelajaran Ekspositori yang memiliki Motivasi berprestasi tinggi

A2B2= Hasil belajar siswa yang dibelajarkan dengan strategi pembelajaran Ekspositori yang memiliki Motivasi berprestasi Rendah

Teknik analisis data yang digunakan adalah teknik statistik deskriptif dan inferesial. Teknik statistik deskriptif digunakan untuk mendeskripsikan data penelitian dengan daftar distribusi frekuensi dan membuat histogram kemudian dihitung mean, median, modus, dan standard deviasinya. Teknik statistik inferesial digunakan untuk menguji hipotesis penelitian dengan teknik ANAVA dua jalur dengan desain faktorial $2 \times 2$ dan taraf signifikansi 0,05 . Uji normalitas data dan uji homogenitas varians dilakukan terlebih dahulu sebelum teknik ANAVA dilakukan. Rumusan hipotesis statistik dinyatakan sebagai berikut:

Hipotesis $1 \quad:$ Ho $: \mu \mathrm{A} 1 \leq \mu \mathrm{A} 2$

$\mathrm{Ha}: \mu \mathrm{A} 1>\mu \mathrm{A} 2$

Hipotesis $2 \quad:$ Ho $: \mu \mathrm{B} 1 \leq \mu \mathrm{B} 2$

Ha $: \mu \mathrm{B} 1>\mu \mathrm{B} 2$

Hipotesis $3 \quad$ :Ho : Interaksi $\mathrm{A}><\mathrm{B}=0$

Ha : Interaksi $\mathrm{A}><\mathrm{B} \neq 0$

\section{HASIL DAN PEMBAHASAN}

Pengujian hipotesis dilakukan menggunakan teknik analisis varians (ANAVA). Untuk keperluan analisis varians, data yang diperlukan dapat dilihat pada Tabel 2.

Tabel 2. Data Hasil Belajar Bahasa Inggris Siswa

\begin{tabular}{|c|c|c|c|c|c|c|}
\hline \multirow[b]{2}{*}{$\begin{array}{c}\text { Motivasi } \\
\text { Berprestasi }\end{array}$} & \multicolumn{4}{|c|}{ Strategi Pembelajaran } & \multirow{2}{*}{\multicolumn{2}{|c|}{ Total }} \\
\hline & \multicolumn{2}{|c|}{$\begin{array}{c}\text { Strategi Quantum } \\
\left(A_{1}\right)\end{array}$} & \multicolumn{2}{|c|}{$\begin{array}{c}\text { Strategi Ekspositori } \\
\left(A_{2}\right)\end{array}$} & & \\
\hline \multirow{4}{*}{$\begin{array}{c}\text { Tinggi } \\
\left(B_{1}\right)\end{array}$} & $n_{A 1 B 1}=$ & 21 & $n_{A 1 B 1}=$ & 17 & $n_{A 1 B 1}=$ & 38 \\
\hline & $\sum x=$ & 670 & $\sum x=$ & 451 & $\sum x=$ & 1121 \\
\hline & $\sum x^{2}=$ & 9709 & $\sum x^{2}=$ & 12069 & $\sum x^{2}=$ & 33647 \\
\hline & $\bar{x}=$ & 31.90 & $\bar{x}=$ & 26.52 & $\bar{x}=$ & 29.22 \\
\hline \multirow{4}{*}{$\begin{array}{c}\text { Rendah } \\
\left(B_{2}\right)\end{array}$} & $n_{A 1 B 2}=$ & 14 & $n_{A 1 B 2}=$ & 18 & $n_{A 1 B 2}=$ & 32 \\
\hline & $\sum x=$ & 367 & $\sum x=$ & 525 & $\sum x=$ & 892 \\
\hline & $\sum x^{2}=$ & 15518 & $\sum x^{2}=$ & 15467 & $\sum x^{2}=$ & 30715 \\
\hline & $\bar{x}=$ & 26.21 & $\bar{x}=$ & 29.17 & $\bar{x}=$ & 27.69 \\
\hline \multirow{3}{*}{ Total } & $n_{t}=$ & 35 & $n_{t}=$ & 35 & $n_{t}=$ & 70 \\
\hline & $\sum x=$ & 1037 & $\sum x=$ & 976 & $\sum x=$ & 2013 \\
\hline & $\sum x^{2}=$ & 31287 & $\sum x^{2}=$ & 27536 & $\sum x^{2}=$ & 58823 \\
\hline
\end{tabular}




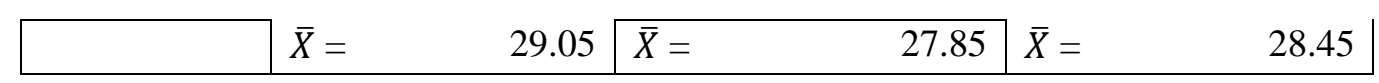

Hasil perhitungan ANAVA seperti yang ditunjukkan dalam Tabel 3 yaitu rangkuman analisis factorial $2 \times 2$.

Tabel 3. Rangkuman Analisis Faktorial $2 \times 2$

\begin{tabular}{|l|r|r|r|r|r|l|}
\hline \multicolumn{1}{|c|}{ Sumber Varians } & \multicolumn{1}{c|}{ JK } & \multicolumn{1}{c|}{ dk } & \multicolumn{1}{c|}{ RJK } & $\boldsymbol{F}_{\text {hitung }}$ & $\boldsymbol{F}_{\text {tabel }}$ & Kesimpulan \\
\hline Strategi Pembelajaran & 53.16 & 1 & 53.16 & 6,39 & 3.98 & Signifikan \\
Motivasi Berprestasi & 45.87 & 1 & 45.87 & 5,51 & 3.98 & Signifikan \\
Interaksi & 286.9 & 1 & 286.9 & 34,50 & 3.98 & Signifikan \\
Antar Kelompok & 386 & 3 & 128.7 & & & \\
Dalam Kelompk & 548.9 & 66 & 8.193 & & & \\
\hline Total & 934.9 & 69 & & & & \\
\hline
\end{tabular}

Pengujian hipotesis pertama yang menyatakan hasil belajar Bahasa Inggris siswa yang diajar dengan Strategi Pembelajaran Quantum, lebih tinggi daripada hasil belajar siswa yang diajar dengan Strategi Pembelajaran Ekspositori, hipotesis statistiknya adalah:

Ho $: \mu_{A 1} \leq \mu_{A 2} \quad H a: \mu_{A 1}>\mu_{A 2}$

Berdasarkan perhitungan ANAVA faktorial 2x2 diperoleh $F_{\text {hitung }}=6,39$ sedangkan nilai $F_{\text {tabel }}=3,98$ untuk dk $(1,69)$ dan taraf nyata $\alpha=0,05$. Ternyata nilai $F_{\text {hitung }}>F_{\text {tabel }}$ sehingga pengujian hipotesis menolak Ho dan menerima Ha dan menolak H0. Dengan demikian dapat ditarik kesimpulan bahwa hasil belajar Bahasa Inggris siswa yang diajar dengan Strategi Pembelajaran Quantum lebih tinggi dibanding dengan Strategi Pembelajaran Ekspositori teruji kebenarannya secara empirik. Hal ini juga terlihat dari ratarata hasil belajar Bahasa Inggris yang diajar dengan Strategi Pembelajaran Quantum lebih tinggi dari hasil belajar Bahasa Inggris yang diajarkan dengan Strategi Pembelajaran Ekspositori.

Pengujian hipotesis kedua yang menyatakan hasil belajar Bahasa Inggris siswa yang memiliki Motivasi Berprestasi Tinggi lebih tinggi daripada hasil belajar siswa yang memiliki Motivasi Berprestasi Rendah, hipotesis statistiknya adalah:

$H o: \mu_{B 1} \leq \mu_{B 2} \quad H a: \mu_{B 1}>\mu_{B 2}$

Berdasarkan perhitungan ANAVA

faktorial $2 \times 2$ diperoleh $F_{\text {hitung }}=5,51$ sedangkan nilai $F_{\text {tabel }}=3.98$ untuk dk (1.69) dan taraf nyata $\alpha=0.05$. Ternyata nilai $F_{\text {hitung }}>F_{\text {tabel }}$ sehingga pengujian hipotesis menolak Ho dan menerima Ha dan menolak H0. Dengan demikian dapat ditarik kesimpulan bahwa hasil belajar Bahasa Inggris siswa yang memiliki Motivasi Berprestasi Tinggi lebih tinggi dibanding siswa yang memiliki memiliki Motivasi Berprestasi Rendah teruji kebenarannya secara empirik. Hal ini juga terlihat dari rata-rata hasil belajar Bahasa Inggris yang memiliki Motivasi Berprestasi Tinggi lebih tinggi dari hasil belajar Bahasa Inggris yang memiliki Motivasi Berprestasi Rendah.

Pengujian hipotesis ketiga menyatakan bahwa terdapat interaksi antara Strategi Pembelajaran dan Motivasi Berprestasi dalam meningkatkan hasil belajar Bahasa Inggris.:

Ho: $A \times B=0 \quad H a: A \times B \neq 0$

Berdasarkan perhitungan ANAVA

faktorial $2 \times 2$ diperoleh $F_{\text {hitung }}=34,50$ sedangkan nilai $F_{\text {tabel }}=3.98$ untuk dk (1.69) dan taraf nyata $\alpha=0.05$. Ternyata nilai $F_{\text {hitung }}>F_{\text {tabel }}$ sehingga pengujian hipotesis menolak Ho dan menerima Ha. Dengan demikian dapat ditarik kesimpulan bahwa terdapat interaksi antara Strategi Pembelajaran dan Motivasi Berprestasi dalam meningkatkan hasil belajar Bahasa Inggris siswa teruji kebenarannya secara empirik.

Dengan demikian untuk melihat perbandingan kombinasi interaksi antara Strategi Pembelajaran dan Motivasi Berprestasi terhadap hasil belajar Bahasa Inggris, maka dilakukan uji lanjut dengan Uji Scheffe. Perhitungan untuk uji Scheffe. Rangkuman hasil perhitungan Uji Scheffe dapat dilihat pada Tabel 4. di halaman berikut ini. 
Tabel 4. Rangkuman Hasil Uji Scheffe

\begin{tabular}{|l|l|c|c|}
\hline \multicolumn{2}{|c|}{ Hipotesis Statistik } & $\boldsymbol{F}_{\text {hitung }}$ & $\begin{array}{c}\boldsymbol{F}_{\text {tabel }}(\mathbf{3}, \mathbf{6 9}) \\
\boldsymbol{\alpha}=\mathbf{0 , 0 5}\end{array}$ \\
\hline Ho: $\mu_{A 1 B 1}=\mu_{A 2 B 1}$ & Ha: $\mu_{A 1 B 1}>\mu_{A 2 B 1}$ & 6.07 & 2,74 \\
\hline Ho: $\mu_{A 1 B 1}=\mu_{A 1 B 2}$ & Ha: $\mu_{A 1 B 1}>\mu_{A 1 B 2}$ & 5.75 & 2,74 \\
\hline Ho: $\mu_{A 1 B 1}=\mu_{A 2 B 2}$ & Ha: $\mu_{A 1 B 1}>\mu_{A 2 B 2}$ & 3.19 & 2,74 \\
\hline Ho: $\mu_{A 2 B 1}=\mu_{A 1 B 2}$ & Ha: $\mu_{A 2 B 1}<\mu_{A 1 B 2}$ & 0.32 & 2,74 \\
\hline Ho: $\mu_{A 2 B 2}=\mu_{A 2 B 2}$ & Ha: $\mu_{A 2 B 2}<\mu_{A 2 B 2}$ & 2.77 & 2,74 \\
\hline Ho: $\mu_{A 2 B 1}=\mu_{A 2 B 2}$ & Ha: $\mu_{A 2 B 1}>\mu_{A 2 B 2}$ & 2.8 & 2,74 \\
\hline
\end{tabular}

Hasil pengujian lanjut di atas, menunjukan adanya interaksi antara Strategi Pembelajaran dan Motivasi Berprestasi terhadap hasil belajar Bahasa Inggris siswa. Interaksi Strategi Pembelajaran dan Motivasi Berprestasi dapat ditunjukkan seperti Gambar 4.9 berikut ini.

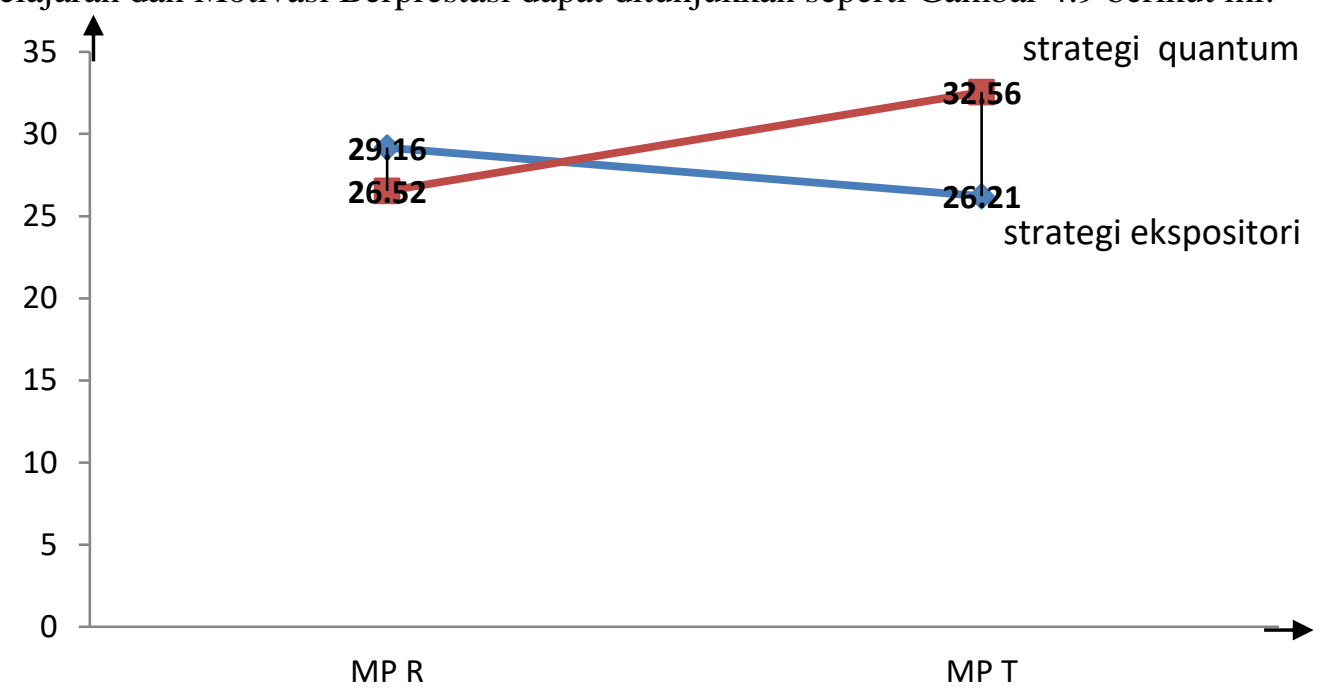

Gambar 1. Interaksi Antara Pembelajaran Dengan Strategi Pembelajaran Dan Motivasi Berprestasi

\section{PEMBAHASAN}

Dari hasil pengolahan data yang dilakukan terdapat perbedaan hasil belajar Bahasa Inggris antara peserta didik yang dibelajarkan dengan Strategi Pembelajaran Quantum dan peserta didik yang dibelajarkan dengan Strategi Ekspositori yaitu rata-rata hasil belajar Bahasa Inggris peserta didik yang belajarkan dengan menggunakan Strategi Pembelajaran Quantum lebih tinggi dibandingkan dengan peserta didik yang dibelajarkan dengan menggunakan Strategi Ekspositori. Kenyataan ini membuktikan bahwa penggunaan Strategi Pembelajaran Quantum lebih baik dalam meningkatkan pengetahuan peserta didik dalam pembelajaran Bahasa Inggris daripada penggunaan Strategi Ekspositori.

Disamping itu strategi pembelajaran quantum bertujuan menggugah sepenuhnya kemampuan belajar para pelajar, membuat belajar menyenangkan dan memuaskan bagi mereka dan memberikan sumbangan sepenuhnya kepada kebahagiaan, kecerdasan, kompetensi, dan keberhasilan mereka sebagai manusia. Seluruh kegiatan belajar manusia dapat dikatakan mempunyai empat unsur yaitu : persiapan, penyampaian, pelatihan, dan penampilan. Oleh karena itu peran guru dalam pembelajaran quantum sebagai fasilitator yang mengarahkan siswa untuk menemukan dan mengkonstruk sendiri pengetahuannya. Seperti pendapat Nurhadi (2004) Strategi pembelajaran quantum merujuk pada prinsip belajar bermakna yaitu belajar bermakna didasari oleh filosofi belajar konstrktivisme. Inti ajarannya adalah proses belajar akan produktif jika siswa terlibat aktif dalam proses belajar.

Hal ini menunjukkan bahwa motivasi berprestasi signifikan untuk membedakan hasil belajar Bahasa Inggris siswa, yang hasil belajar Bahasa Inggris dengan motivasi berprestasi rendah lebih baik dibelajarkan dengan strategi pembelajaran Ekspositori. Hal ini sesuai dengan 
pendapat Ausbel dalam Driscoll (1993) bahwa pada dasarnya pembelajaran ekpositori (expository learning) sama dengan pembelajaran yang terjadi dengan belajar menerima. Hal senada dikemukakan Romiszowski (1981) bahwa pendekatan ekspositori adalah pendekatan pembelajaran yang didasarkan pada proses belajar bermakna menerima (meaningfull reception learning). Strategi pembelajaran ekspositori merupakan bentuk dari pendekatan pembelajaran yang berorientasi kepada guru. Peranan guru dalam proses pembelajaran sangat dominan. Guru menyampaikan materi secara terstruktur dengan harapan materi pelajaran yang disampaikan dapat dikuasai siswa dengan baik.

Strategi pembelajaran Quantum merupakan Strategi Pembelajaran yang mengacu kepada kebutuhan peserta didik dalam hal alasan sesungguhnya mengapa seseorang membaca yaitu karena ingin memperoleh sesuatu teks tertulis yang dibacanya, apakah itu berupa fakta, ide, kesenangan atau perasaan (Nuttal, 1988:3). Memahami sebuah teks bacaan dilakukan sebagian besar dengan menganalisa kata-kata dan kalimat demi kalimat yang terdapat dalam bacaan dengan bantuan kamus atau guru. Pemanfaatan pengetahuan yang sudah ada pada peserta didik sebelumnya kurang menjadi perhatian guru. Strategi Pembelajaran Quantum dimana menurut Degeng (1989) dalam kaitan pembelajaran yang dimiliki seseorang sangat berhubungan dengan perolehan dan retensi pengetahuan baru yang dipelajarinya.

Pengujian hipotesis yang kedua menunjukkan bahwa hasil belajar Bahasa Inggris dari siswa yang memiliki motivasi berprestasi tinggi lebih tinggi daripada hasil belajar Bahasa Inggris dari siswa yang memiliki motivasi berprestasi rendah. Hasil ini membuktikan bahwa motivasi berprestasi tinggi signifikan untuk membedakan hasil belajar Bahasa Inggris. Motivasi berprestasi dalam penelitian ini dibedakan atas motivasi berprestasi tinggi dan motivasi berprestasi rendah. Munandar (1992:67) juga menjelaskan bahwa motivasi berprestasi adalah berpikir kreatif, berpikir untuk memberikan berbagai kemungkinan jawaban berdasarkan informasi yang diberikan dengan penekanan pada keragaman jumlah, kesesuaian, lebih bebas dan terbuka. Kajian Munandar selaras dengan Seifert (1992:89), bahwa motivasi berprestasi memiliki empat ciri utama yaitu : kelancaran (fluency), (2) kelenturan (flexibility), (3) keaslian (originality), dan (4) perluasan (elaboration).

Hasil penelitian menunjukkan bahwa rata-rata hasil belajar Bahasa Inggris peserta didik yang memiliki Motivasi Berprestasi tinggi lebih tinggi daripada hasil belajar Bahasa Inggris peserta didik yang memiliki Motivasi Berprestasi Rendah. Hal ini mengindikasikan bahwa peserta didik yang memiliki Motivasi Berprestasi tinggi lebih mampu memahami pelajaran Bahasa Inggris dibandingkan dengan peserta didik yang memiliki Motivasi Berprestasi Rendah. Sehingga dalam hal ini peserta didik mampu memahami, menyampaikan bahasa dengan baik, benar dan memiliki makna yang dapat dimengerti oleh peserta didik.Berdasarkan karakteristik Motivasi Berprestasi tinggi, peserta didik yang memiliki Motivasi Berprestasi akan memperoleh hasil belajar yang lebih tinggi daripada peserta yang memiliki Motivasi Berprestasi rendah, khususnya dalam pembelajaran Bahasa Inggris.

Pengujian hipotesis yang ketiga terdapat interaksi antara strategi pembelajaran dan motivasi berprestasi dalam mempengaruhi hasil belajar Bahasa Inggris siswa SMP Negeri Di Kabupaten Labura. Apabila dilihat dari ratarata nilai hasil belajar Bahasa Inggris kelompok siswa dengan motivasi berprestasi tinggi dan dibelajarkan dengan strategi pembelajaran Ekspositori lebih baik dibandingkan dengan rata-rata hasil belajar Bahasa Inggris kelompok siswa dengan motivasi berprestasi tinggi dan dibelajarkan dengan strategi pembelajaran Quantum. Kemudian rata-rata hasil belajar Bahasa Inggris kelompok siswa dengan motivasi berprestasi rendah dan dibelajarkan dengan strategi pembelajaran Ekspositori lebih rendah dibandingkan dengan rata-rata hasil belajar Bahasa Inggris kelompok siswa dengan motivasi berprestasi rendah dan dibelajarkan dengan strategi pembelajaran Quantum. Hal ini bermakna bahwa bagi kelompok siswa dengan motivasi berprestasi rendah lebih baik menggunakan strategi pembelajaran Quantum dibandingkan dengan strategi pembelajaran ekspositori, walaupun perbedaannya tidak terlalu signifikan. Dengan demikian dapatlah ditarik kesimpulan bahwa strategi pembelajaran dan motivasi berprestasi cukup signifikan mempengaruhi hasil belajar Bahasa Inggris siswa. 
Temuan penelitian menunjukkan bahwa terdapat interaksi antara strategi pembelajaran dan Motivasi Berprestasi terhadap hasil belajar Bahasa Inggris. Peserta didik yang memiliki Motivasi Berprestasi tinggi yang dibelajarkan dengan Strategi Pembelajaran Quantum memperoleh hasil belajar Bahasa Inggris yang lebih tinggi daripada peserta didik yang memiliki Motivasi Berprestasi Rendah yang dibelajarkan dengan menggunakan Strategi Ekspositori. Demikian pula peserta didik yang memiliki Motivasi Berprestasi Rendah yang dibelajarkan dengan menggunakan Strategi Pembelajaran Ekspositori memperoleh hasil belajar Bahasa Inggris yang lebih rendah dibandingkan dengan peserta didik yang dibelajarkan dengan menggunakan Strategi Quantum. Walaupun dalam penelitian ini tidak terdapat perbedaan yang signifikan. Hal ini mengindikasikan adanya interaksi antara penggunaan strategi pembelajaran dengan Motivasi Berprestasi terhadap hasil belajar Bahasa Inggris peserta didik.

\section{PENUTUP}

Berdasarkan pengolahan data dan pembahasan terhadap hasil penelitian yang dikemukakan sebelumnya maka dalam penelitian ini dapat disimpulkan bahwa :

1. Hasil belajar Bahasa Inggris siswa yang diajar dengan menggunakan Strategi pembelajaran Quantum lebih tinggi dari hasil belajar Bahasa Inggris siswa yang diajar dengan menggunakan Strategi pembelajaran Ekspositori.

2. Hasil belajar Bahasa Inggris siswa yang memiliki motivasi berprestasi tinggi lebih tinggi daripada hasil belajar Bahasa Inggris siswa yang memiliki motivasi berprestasi rendah.

3. Terdapat interaksi antara penggunaan Strategi Pembelajaran dan Motivasi Berprestasi dalam mempengaruhi hasil belajar Bahasa Inggris siswa. Dari hasil pengujian lanjut ternyata siswa yang memiliki motivasi berprestasi tinggi memperoleh hasil belajar Bahasa Inggris lebih tinggi jika diajar dengan menggunakan Strategi pembelajaran Quantum daripada Strategi pembelajaran ekspositori, sedangkan siswa yang memiliki motivasi berprestasi rendah lebih tinggi hasil belajarnya jika diajar dengan Strategi pembelajaran ekspositori daripada Strategi pembelajaran Quantum.

\section{DAFTAR PUSTAKA}

Arrends, R.I. (2004).Learning To Teach.Sixth Edition.New York: McGraw-Hill Companies

Brown, H. D,( 2000). Principles of Learning and Teaching. New York: Logman.

. (2004). Language Assessment and Principles in Classroom Practices. New York: Pearson Education.

Burden, Pul R. and David M. M. Byrd.(1999). Methods for Effective Teaching. Boston: Allynand Bacon.

Buzan, T. (2002). Gunakan Kepala Anda: Teknik Berpikir, Belajar dan Membangun Otak. Alih Bahasa: Toni Rinaldo. Jakarta

Caplin. (1999). Kamus Lengkap Psikologi. Jakarta: RajaGrafindo Persada

Davies, I. K. (1981). Instructional Technique. New York: McGraw-Hill Book Company.

De Porter, dkk. (2006). Quantum Teaching : Memperaktikkan Quantum Learning di Ruang- ruang kelas. Bandung : Kaifa

DePorter, B dan Hernacki, M, (2004). Quantum Learning Alih Bahasa : Ary Nilandari. Bandung : Kaifa.

--------. (2007). Quantum Learning : Membiasakan Belajar Nyaman dan menyenangkan. Bandung : Kaifa.

Dennison, Paul E. dan Dennison, Gail E. (2002). Braim Gym. Jakarta: Gramedia Widiasarana Indonesia.

Dick and Carey. (2005). The Systematic Design of Instructional, New York : Harper Collins Publishers.

Driscoll, M. P. (1993). Psyichology of Learning for Instruction. Boston: Florida State University.

Gagnẻ, Robert M and Briggs, Leslie J ( 1979). Principles of Instructional Design. Second Edition.New York : Holt, Rinehart and Winston.

Gagne, R. M. \& Driscoll, Marcy P. (1989). Essentials of Learnings for Instruction. New Jersey: Prentice Hall.

Gagne and Briggs, (1992). Principles of Instructional Design. Florida: Hotlad Winston.

Gunawan, Adi W. (2004). Born to be a Genius. Jakarta: Gramedia Pustaka Utama.

-------. (2006). Genius Learning Strategy. Jakarta: Gramedia Pustaka Utama.

Hernowo. (2004). Vitamin Bagaimana Mengubah Diri Lewat Membaca dan 
Menulis. Bandung: Mizan Learning Center

Iskandar. (2009). Psikologi Pendidikan. Jakarta : GP Press

Manurung, B. (2012) . Pengaruh Strategi Pembelajaran Dan Motivasi Belajar Tehadap Hasil Belajar Bahasa Indonesia Siswa SMA Metgodist-1 Medan. Tesis. Unimed.

McCleland, D. C. (1949). The Projective Expresion of Needs. American Psychological Association. Inc

Merrill, David. (1983), Instructional Design Theories and Models: an Overview of their Current Status, Instructional Design: What is it? New Jersey: Publishers Hildshale.

Merril, M.D, ( 1994). Instructional Design Theory. Englewood Cliffs, New Jersey : Menyemaih Benih Teknologi Pendidikan. Jakarta: Kecana.

Meier, Dave, 2003. The Acclerated Learning Hand Book. Jakarta : Kaifa. Instruction Theories in Action .Reigeluth (ed). New Jersey : Lawrence Erlbaum As.

Miarso, Yusufhadi. (2005). Menyemaih Benih Teknologi Pendidikan. Jakarta: Kecana

Nasution, S. (2006). Kurikulum dan Pengajaran. Jakarta: Bumi Aksara.

Nunan, D. (1991). Language Teaching Methodology. A Textbook for Teachers. United States. United State of America : Prentice Hall

Nurhadi. (2004). Kurikulum 2004 Pertanyaan dan jawaban. Jakarta: Grasindo.

Olson, Chester L. (1987). Essential of Statistic Making Sense of Data . Boston: Allyn and Bacon.

Prashnig, Barbara.(2007).The power Of Learning styles. Bandung: Kaifa

Purwanto, N. M. (2007). Psikologi Pendidikan. Bandung: Remaja Rosdakarya.

Reigeluth, Charles M.(1983), InstructionDesign Theories and Models: An Overview of Their Current Status. London: Lawrence Erlbaum Asssociates Publishers

Reigeluth, M.C. (1999). Instructional-Design Theories and Models. Volume II. A Paradigm Of Instructional Theory. London : Lawrence Erlbaum Associates.

Richey and Seels (1994). Teknologi Pembelajaran. Defenisi dan kawasannya. Jakarta : IPTPI
Romiszowski,AJ. (1981). Designing Instruktional Systems. London : Kogan Page

Sagala, Syaiful. (2003). Konsep dan Makna Pembelajaran. Bandung: Alfabeta.

Sanjaya, Wina. (2008). Strategi Pembelajaran. Jakarta: Kencana.

Seliger,Herbert. 1989. Second Language Research Methods. British: Oxford University Press.

Silberman, Mel. 2000. Active Learning. Yogyakarta: Yappendis.

Sudjana. (2005). Metoda Statistika. Bandung : Tarsito

Winkel,S.(2009). Psikologi Pengajaran. Yogyakarta : Media Abadi. 